\title{
The ECB's Enhanced Credit Support
}

Keynote Address by

Jean-Claude Trichet, President of the ECB

at the University of Munich, 13 July 2009

\author{
CESIFO WORKING PAPER No. 2833 \\ CATEGORY 7: MONETARy Policy AND InTERnATIONAL FinANCE \\ OCTOBER 2009 \\ An electronic version of the paper may be downloaded \\ - from the SSRN website: \\ www.SSRN.com \\ - from the RePEc website: \\ www.RePEc.org \\ - from the CESifo website: \\ www.CESifo-group.org/wp
}




\title{
THE ECB'S ENHANCED CREDIT SUPPORT
}

\author{
Keynote address by \\ Jean-Claude Trichet \\ President of the European Central Bank
}

at the University of Munich

Munich, I 3 July 2009 


\section{Introduction}

Ladies and gentlemen,

It is a pleasure to be in Munich today. I would like to thank the organisers, Professor Hans-Werner Sinn of CESifo and Marc Beise, the chief economics editor of Süddeutsche Zeitung, for inviting me here. I am delighted to have this opportunity to talk about the ECB's policy actions in these times of exceptional challenges for monetary policy-makers. I also hope to contribute to the academic debate, ensuring the active exchange of views between academic and policy-making circles that is so necessary for both sides.

These Munich seminars have become one of the best-known events of their kind in Europe. More events of this type are needed. CESifo - with its close links to the University of Munich - has established one of the most active and widely respected platforms for European policy debate. It is therefore a great pleasure for me to be here talking about the field in which European integration has progressed the furthest, namely monetary policy-making.

In the last two years the environment in which we operate has changed very profoundly. We went through a period of global financial panic, and we are still in very difficult and uncharted territory. I am therefore pleased to report that the policy toolkit of the European Central Bank - a young institution albeit benefiting from a very solid legacy - has been up to the challenge. The ECB's actions since the onset of the financial crisis have been bold, and yet firmly anchored within the medium-term framework of our monetary policy strategy.

We took unprecedented action in August 2007, on day one of the financial turmoil, when few others had identified the potential for macro financial disruption. We stepped boldly into the breach when the collapse of a major financial player last autumn caused interbank funding markets to stop functioning. Moreover, since the crisis began, not one systemically important financial institution has collapsed in the euro area. This is no small achievement, given the damage we have observed as a result of such events.

Since October 2008, our key policy rate has been cut from $4.25 \%$ to $1 \%$. In addition, and just as importantly, we have embarked on a policy of fully accommodating banks' liquidity needs. This very bold and necessary step has avoided a situation in 
which stressed liquidity conditions spiral into a threat to the viability of our banking system as a whole.

And we have been far from passive in recent months. We have broadened the set of measures that, collectively, represent the policy toolkit that we call "enhanced credit support". I will talk more about that policy today, explaining in detail why the approach of "enhanced credit support" was developed, what its main elements are, and how it is working for the euro area economy - not just the banks, but also for the European businesses and households. I will also explain how the set of underlying policies can be unwound once the financial crisis eases or if upside risks to price stability emerge.

But let me first say a few words about our current assessment of the situation in the euro area. I will take for granted that we share a common understanding of the severity of recent events. Right now, economic activity is expected to continue declining for the remainder of this year, but significantly less strongly than it did in the first quarter of 2009. Looking ahead into next year, following a period of stabilisation, a gradual recovery with positive quarterly growth rates is expected by mid-2010. This is our working hypothesis at this stage. The significant policy stimuli in the major economic areas should support growth around the world, including the euro area.

Inflation fell into slightly negative territory in June. This outcome was anticipated and mainly reflects the earlier sharp decline in global oil prices. It is therefore a welcome development, and one that supports households' real incomes. Looking ahead, we expect prices to remain dampened over the medium term. We are particularly pleased that all indicators of inflation expectations over the medium to longer term remain firmly anchored in line with the Governing Council's aim of keeping inflation rates below, but close to, $2 \%$. Our success in firmly anchoring inflation expectations is of crucial importance, and I will talk more about this later on.

Let me also make some general remarks on the principal achievements of the first ten years of the euro. 


\section{The euro: performance and institutional foundation}

The euro is the most visible symbol of European unification. The euro is now the shared currency of 16 countries and 329 million people. The number of citizens united by the single currency already is in the same order of magnitude as the population of the United States of America. The euro was introduced more than ten years ago - in II countries at the time. Ten years is a short period of time in historical terms, but long enough to take stock of what has been achieved.

The main achievement can be summarised in a single sentence: the euro is a very stable currency and all the institutional requirements are in place to preserve its solidity in the future. This is what defines success in monetary affairs.

Being here in Munich, I would say that the promise that the euro will be "stabil wie die Mark" has been kept. A glance at the inflation rates makes this clear: the average annual inflation rate in the euro area in the first eleven years of the euro will be around $2.0 \%$, notwithstanding the tough challenges of successive oil and commodity shocks we had to cope with. This will even be slightly lower than the average annual inflation rate in Germany in the 1990s.

Moreover, the priority given to price stability in the euro area has by no means been at the expense of employment. Between 1999 and 2008, the number of people employed in the euro area increased by more than 16 million - significantly more than in the US during the same period. In the preceding period, from 1990 to 1998 , the increase in employment was less than 6 million for the same time span. This can be seen as confirmation that a monetary policy oriented towards price stability is fully compatible with job creation. This is not to say that we have not faced new challenges since the crisis erupted, and that this is a time for complacency. But those figures put into perspective what has been achieved since the start of the euro.

Speaking in Germany, and having been the first governor of the politically independent Banque de France since I January 1994, I will say that we are all aware that assigning an independent central bank to the pursuit of price stability was both a historical necessity and a key ingredient in economic success. It is also well-known that the solid tradition of the Deutsche Bundesbank sprung out of the painful experiences of the more distant German monetary history in the first half of the $20^{\text {th }}$ century, in particular the German hyperinflation of the early 1920s, which has 
left deep scars in the collective memory of both Germany and Europe. In a sense, the German experience between the two world wars demonstrates how painful deviations from price stability can be - both in economic and in political terms.

Firm lessons were learned from history in Germany, in particular in the period of the great inflation of the seventies, where the Bundesbank, and a very small number of independent central banks like the Swiss National Central Bank, gained a worldwide reputation for their ability to control inflation. A key ingredient for this success, on top of their independence, was an explicit monetary policy strategy. In the case of the Bundesbank, this included a medium-term policy orientation, the importance attached to monetary developments, and an element of rule-based behaviour in policy determination.

These lessons of history were shared all over Europe. I was the Governor of the Banque de France when its independence was granted in January 1994, five years before the euro. As soon as independence was granted to the 200-year-old institution, applying its ancient motto "La sagesse fixe la fortune", which I could translate as "Wisdom disciplines fortune", we defined price stability as an inflation rate below $2 \%$ over the medium term. We also worked out a monetary policy concept based on a two-pillar strategy, including a monetary pillar. I was particularly proud that average inflation in France was $1.4 \%$ per year over five years from 1994 to 1999, fully in line with the definition of price stability.

With the creation of the euro, that stability culture has been fully "Europeanised", and was given a legal face in the Maastricht Treaty and an institutional face in the form of the European Central Bank. To sum up, what has been achieved in the first ten years of the euro is substantial, both in economic terms and in institutional terms. Very solid foundations are in place in order to preserve these achievements, and this gives us confidence for the future.

Let me now turn to the main part of my speech: the current crisis and the toolkit developed by the ECB in response. 


\section{Origins and development of the financial crisis}

In looking back on the years prior to the eruption of the crisis, we have to acknowledge that there was a dramatic shift in focus in large parts of the financial sector - away from facilitating trade and real investment towards unfettered speculation and financial gambling. Hans-Werner Sinn has called these deviations "Kasino-Kapitalismus". Of course, we all know that financial liberalisation and financial innovation have made important contributions to the overall productivity of our economies. The securitisation of loans, for example, had tremendous potential for the diversification and efficient management of economic risk. But securitisation was implemented in such a way that banks and non-banks were able not only to sell loans, but also to place them fully off-balance sheet as soon as they had been granted. This resulted in weak underwriting standards and a lack of incentives for lenders to conduct prudent screening of loans.

This is true for the most recent product innovations in the field of securitisation. But it is not true for a particular financial innovation that is more than 200 years old and was in particular introduced in Germany under the name "Pfandbrief': covered bonds. I will return to this asset class of covered bonds later.

The credit boom leading up to the crisis was exacerbated by three multipliers:

- first, incentives: ill-designed compensation schemes for loan managers and traders that reinforced the shortening of their time horizons;

- second, complexity: increasingly complicated and opaque financial instruments that made it difficult for holders of securities to assess the quality of the underlying investments; and

- third, global macroeconomic imbalances: a chronic shortage of savings in some industrialised economies was made possible by an excess of savings in other parts of the world.

In mid-2007 the turmoil erupted. This was sudden, but not entirely unexpected. Indeed, as long ago as January 2007, I myself expressed the views of my fellow 
central bankers, when I indicated that markets would need to prepare for a general reassessment and repricing of risk, which was clearly underestimated at that time.'

Some months later, this repricing occurred very suddenly, triggering turbulences in the interbank market. The consequences of this very sharp repricing threw the credit boom into reverse. The asset cycle turned, and many of the missing links in the financial chain were exposed.

The collapse in mid-September of last year of a major financial institution transformed the financial turmoil into a global financial crisis. Immediately, financial intermediaries restored liquidity buffers, scaled down their balance sheets and tightened lending conditions. They dramatically reduced exposure to the risks that they had imprudently accumulated during the period of financial euphoria. Collectively, they engaged in a large-scale "deleveraging" process. Banks' intermediation was sharply reduced, and loans to companies were curtailed.

\section{Interbank market spreads}

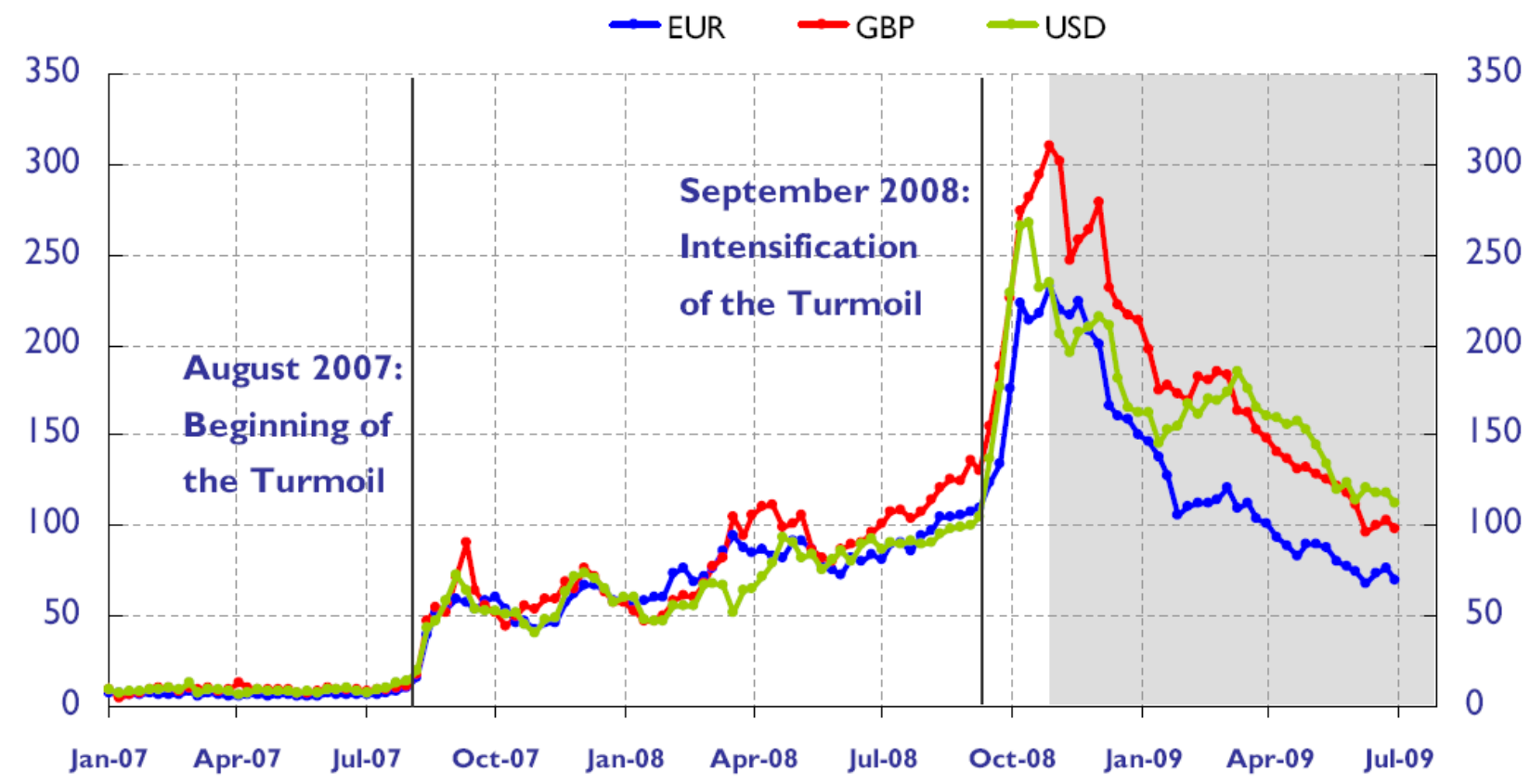

Note: Spreads are the difference between I2-month Euribor/Libor and Overnight Index Swap rates, in basis points. Source: Bloomberg and ECB's calculations. 
A long-term trend that had brought credit risk spreads on loans extended by international financial intermediaries to historical lows was suddenly reversed. A credit squeeze ensued which took a severe toll on the real economy.

\section{Key characteristics of the euro area}

The ECB has moved pre-emptively and forcefully to counter the adverse consequences of the financial crisis. At all times the ECB's response has been carefully calibrated to the structure of the euro area economy.

Allow me to elaborate on this structure, which differs significantly from those in other advanced economies, notably the United States, which may be the most relevant comparator.

First, there are profound differences in their financial structures. The differences in the composition of funding sources for non-financial corporations are remarkable.

\section{Sources of finance for corporations}

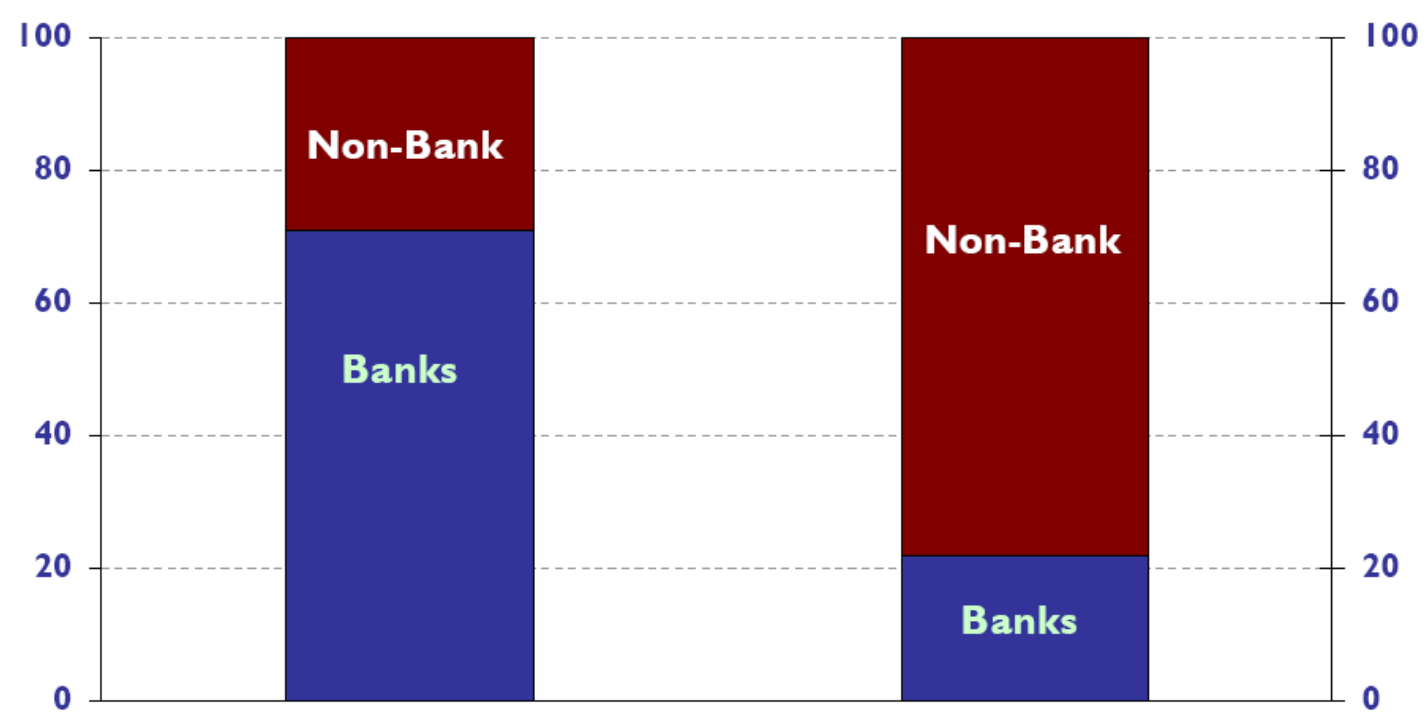

Euro Area United States

Note: Breakdown of the sources of external financing of non-financial corporations, in percent, average 2004 - 2008 
Looking at an average for the last few years, in the euro area bank financing accounted for an average of about two thirds of firm's total external financing. In the United States, by contrast, firms rely to a much larger extent on market-based sources, which make up for more than $75 \%$ of total external financing.

The different financial structures have implications for the appropriate design of the monetary policy response in the face of a crisis that undermines the stability of the financial system. To be effective, ECB policy must focus first and foremost although not exclusively - on the banking sector.

There are also profound differences in the economic structures of the euro area and the United States. Let me, for the sake of brevity, single out three characteristics of the euro area economy that our policies must take into account in order to be effective.

- First, small and medium-sized enterprises, which play a pivotal role in the euro area economy. They are particularly important for growth and job creation. These enterprises cannot generally tap credit markets directly. Guaranteeing continued access to bank credit is vital in order for them to be able to finance their activities.

- Second, the housing market, which in the United States is at the epicentre of the crisis. This is not true for the euro area. At the same time, the euro area is indirectly affected as banks hold toxic assets partly backed by mortgage loans originated in the United States. Forcefully addressing the toxic asset problem is a precondition for reviving credit on both sides of the Atlantic. Where necessary, banks should take full advantage of government measures, particularly as regards recapitalisation.

- Third is the flexibility of the economy. Wages and prices of goods and services are slower to change in the euro area than in the United States. In normal times, this sluggishness has drawbacks as it slows down the adjustment of the economy; in the current circumstances it offers some protection against very bad outcomes, provided that the policy framework provides a solid anchor for private sector expectations. In the euro area, the institutional framework provides such an anchor through the medium-term stability orientation of policies, with fiscal policies geared towards sustainability and a monetary policy 
geared towards price stability. In this environment, overly activist policies may risk destabilising expectations, thereby being counterproductive.

The financial and economic structures I have just described provide the background for our policies.

\section{The ECB's response to the financial crisis}

Let me now turn to the ECB's responses to the financial crisis. Following the intensification of the financial crisis in September of last year - and against the background of rapidly receding inflationary pressures - we have taken monetary policy measures that are unprecedented in terms of their nature, scope and magnitude. These measures fall into two categories: first, conventional measures in the form of interest rate changes; second, what have become known as "nonstandard" measures. The latter, taken together, constitute what I would call the "toolkit" for the ECB's policy of enhanced credit support.

\section{Interest rates}

Before explaining in detail the core elements of ECB policy since August 2007 and in particular since last September, I would like to talk briefly about interest rates - the conventional indicators of stance of monetary policy. Some observers tend to reduce monetary policy to the level of the key policy rate. The lower the policy rate, the argument goes, the more effective monetary policy is in response to a downturn. This view is too simplistic. To compare only the levels of policy rates without consideration for the resulting market rates and other economic variables is to look at just one part of a far broader canvas.

Let me give you a concrete example. At $1 \%$ at the moment, our rate on refinancing operations is higher than the US federal funds rate target range of $0-0.25 \%$. But owing, in particular, to the particularly low level of credit and liquidity premia that are observed in our own money market, this difference in policy rates does not translate into equivalent differences in money market rates. 


\section{Selected monetary policy indicators}

\begin{tabular}{lcc}
\hline & Euro Area & United States \\
\hline Policy rate & 1.00 & $\mathbf{0 . 0 0}-\mathbf{0 . 2 5}$ \\
Interbank rates & & \\
- Unsecured rate (12-month) & 1.64 & 1.73 \\
- Unsecured-secured spread & 0.70 & 1.24 \\
Bank rates (long-term) & 3.99 & 3.52 \\
Credit premium (BBB spread) & 2.22 & 2.59 \\
\hline
\end{tabular}

Note: Data in percent; average May-June 2009. Unsecured rate: I2-month Euribor/Libor; secured rate: I2-month swap. The BBB spread is the difference between the BBB- and AA-rated I0-year corporate bond yields (composite index). Bank rates refer to May 2009. Source: Bloomberg and ECB's calculations.

In the euro area, six-month and twelve-month euro interbank rates are important benchmarks. These rates are widely used by banks to grant floating rate loans to households and companies. These six- and twelve-month rates, denominated in euro, are comparable to the corresponding rates for contracts in US dollars. This is due not only to the fact that spreads between secured and unsecured money market rates at comparable maturities are currently lower than their counterparts in the United States at six-month and twelve-month maturities, but also to our full allotment made of supplying liquidity, which is part of an enhanced credit support. In conclusion, this shows that in the current circumstances, international comparisons of policy rates, if not done with the appropriate qualifications, provide limited information about the effective credit conditions prevailing in individual markets.

\section{Enhanced credit support}

In recent months policy actions have gone beyond cuts in short-term interest rates. They also include non-standard measures. These measures are not identical across currency areas. They reflect the specific needs of the respective financial systems and transmission mechanisms. As you know, Japan has become known for an approach 
termed "quantitative easing" which entails, among other things, the expansion of the monetary base through outright purchases of government bonds. The US Federal Reserve is currently engaged, in particular, in "credit easing", which makes use of direct lending facilities vis-à-vis market participants.

The ECB is engaged in policies that I have characterised as "enhanced credit support". This approach focuses primarily on banks as the main source of credit in the euro area economy and seeks to provide enhanced support for credit provision through specific policies. Hence, one can make the following definition: enhanced credit support constitutes the special and primarily bank-based measures that are being taken to enhance the flow of credit above and beyond what could be achieved through policy interest rate reductions alone.

Our measures currently comprise five building blocks.

\section{Liquidity management measures}

I) When the very significant stress in interbank markets first manifested itself in August 2007, the ECB immediately stepped into the breach and accommodated banks' temporarily elevated liquidity demand, through a fine-tuning operation on a full allotment at policy rate mode. The demand of liquidity was as high as 95 billion euro.

When, in mid-September 2008, interbank trading came to a virtual halt, the ECB temporarily generalised this particular model of liquidity provision: since autumn of last year the unlimited provision of liquidity through "fixed rate tenders with full allotment" has comprised the first important building block of our policy of enhanced credit support.

Our first and primary concern was to maintain the availability of credit for households and companies at accessible rates. The new fixed rate full allotment tender procedure was designed to ensure the effectiveness of monetary policy transmission at a time when borrowing through interbank transactions had become abnormally elevated for many financial institutions. Since autumn of last year we have stood ready to remedy any shortage of liquidity that might occur in our refinancing operations. 
2) The second building block of our new liquidity management approach is the list of assets that we take as collateral. This list was already very long before the crisis. We have enlarged it further and now accept an even wider range of securities as collateral. Government securities account for less than half of the nominal value of the securities on the list. The rest are private securities. By contrast with many other central banks, the ECB already accepted private paper before the crisis. In this sense, we were fairly well prepared for the crisis, as we had a relatively "modern" collateral framework. As a consequence, the total value of these eligible securities is currently $€ \mid 2.2$ trillion, equivalent to $130 \%$ of the GDP of the euro area. This very broad range of eligible collateral has considerably eased banks' liquidity constraints during the crisis.

The first two building blocks offer unlimited refinancing against a very wide range of collateral. However, they can only reach the financial system because of the very large number of counterparties that participate in our refinancing operations. Currently, 2,200 credit institutions in the euro area have the opportunity to refinance themselves with us. This fact demonstrates the scale of our outreach to the financial system in the euro area and its effectiveness in insuring against a systemic liquidity threat.

3) The third building block concerns the lengthening of the maturities of our refinancing operations. In a first step, we lengthened the maturities to up to six months. Just over two weeks ago, we began to provide liquidity for up to one year.

The first such operation, conducted in late June, led to a record amount of $€ 442$ billion of liquidity being supplied to the euro area's banking system. This exceptional outcome amounts to around 5\% of the euro area's GDP and is a sign of banks' enduring demand for liquidity security. Banks are now able to access such new sources of central bank credit with longer-term maturities and borrowing costs at historically low levels. Thanks to this facility, they can resolve the mismatch between the investment side and the funding side of their balance sheets. This is expected to make their liquidity planning horizon longer and less uncertain. It will thereby encourage them to provide credit over and above what could be expected otherwise. 
It may take some time, however, for the extra liquidity to be transformed into credit. Just after the first 12-month funding operation we have seen that some part of the extra liquidity still remains within the banking system and is even coming back to the central bank and being deposited with us temporarily. Banks will have to learn to use the longer-term credit that they obtain from their central banks to expand their longer-term assets rather than increase the availability of short-term liquidity. We remind banks of their responsibility to continue to lend to firms and households at appropriate rates and in suitable volumes. We all have to contribute, each of us with our own responsibility, to the continued functioning of our economy in these very difficult times.

4) The fourth building block is that we are currently providing liquidity in foreign currencies, particularly in US dollars. This is to avoid any shortages and is arranged via swap lines with the Federal Reserve. This demonstrates the considerable degree of cooperation among central banks in order to ease liquidity tensions in the global money markets. In addition, the Eurosystem has signed agreements with the central banks of several European countries in order to improve the provision of euro liquidity to their banking sectors.

\section{Covered bond purchases}

5) The fifth building block was added in May: outright purchases of covered bonds. This measure complements the liquidity management measures I have just described. Covered bonds are debt securities issued by banks, which give them access to funding of a longer-term nature than the ECB's refinancing operations. Covered bonds thus allow banks to manage the maturity mismatch between their assets and liabilities.

Why did we decide to engage in purchases of this particular asset class? Several factors guided our decision.

- First, as I have stressed, in the euro area measures to support the flow of credit to the non-financial sector need to operate first and foremost through banks. Covered bonds were a major source of funds for banks in the euro area before the intensification of the financial crisis last autumn, when the covered bonds market virtually shut down. The Governing Council came to the conclusion that 
the Eurosystem could help to revive this market, in terms of liquidity, issuance and spreads, by engaging in outright purchases of covered bonds.

- Second, covered bonds are different in nature from the various asset-backed securities that became so popular before turning sour with the financial crisis. Importantly, covered bonds do not involve the transfer of the credit risk implied by underlying assets from the issuer to the investor. The credit risk stays with the originator, preserving the incentives for prudent credit risk evaluation and monitoring. We could therefore say that covered bonds are incentive compatible while many asset-backed securities were not, at least not in the way the concept was implemented before the crisis. Given that the financial crisis clearly exposed the dire consequences of the imprudent evaluation of credit risk, the usefulness of more conservative asset classes such as covered bonds, which have proved to be safe assets over time, is obvious.

We are confident that this measure will contribute to support financial markets. The announcement effect has been encouraging. The purchase programme started last week and will be conducted gradually, stretching well into next year. We are already seeing a number of new issuances of covered bonds and a degree of compression in the spreads in this important segment, which might have an influence also on other financial markets.

\section{Monetary and fiscal assignments}

This brings me to the last point in my speech. The ECB's enhanced credit support measures are designed in full respect of the euro area macroeconomic framework. Financial support measures potentially involving the significant transfer of credit risk from financial institutions to the taxpayer clearly fall within the realm of fiscal policy. Our decision to conduct outright purchases of covered bonds is fully consistent with this fundamental principle. While they are expected to be effective in supporting credit, these purchases do not burden the Eurosystem with excessive credit risk.

More generally, I have already mentioned that different environments call for different actions, even if there is agreement among central banks about the ultimate objectives. This helps to explain why the ECB's enhanced credit support measures, by contrast with the concepts of "credit easing" and "quantitative easing", do not 
involve outright purchases of sovereign debt. On this feature, I would like to make three comments, stressing pragmatism, principles and preparations for exit.

First, there is a pragmatic explanation. History matters to a prominent degree. In the United States, for example, in normal times outright purchases and sales of treasury bonds with short maturities belong to the routine toolkit of monetary policy implementation. Given that tradition, it may be a natural step, under nonstandard circumstances, to adapt this procedure by significantly expanding the volume of purchases and focusing on governments bonds with longer maturities.

The Eurosystem comes from a different tradition. For us, "reverse transactions" with banks - on the basis of repurchase agreements or collateralised loans - are the single most important - and in many respects exclusive - instrument in open market operation. Given that tradition, it has been a natural step to extend the maturity of our refinancing operations and make adjustments to the collateral requirements.

Second, principles need to be stressed very firmly. For reasons known to all of us, the euro area has a clear separation of responsibilities. The ECB's enhanced credit support fully respects this separation.

Third, preparations for exit are important. The Governing Council will ensure that the measures taken are quickly unwound, and the liquidity provided is absorbed, once the macroeconomic environment improves. Long-term refinancing operations (like operations with shorter maturity) provide liquidity over a fixed time horizon and run off in a fully predictable way. By contrast, the unwinding of outright purchases typically requires an additional decision, namely whether to hold the securities to maturity - and if not, when to sell. The route taken by the Eurosystem avoids such decisions, since it relies largely on built-in mechanisms for the reabsorption of liquidity.

By their nature, fiscal policies lack a similarly strong built-in mechanism when it comes to the unwinding of stimulus. Discretionary policies need to be invoked to engineer an exit from the current degree of fiscal expansion. A return to sound, sustainable public finances, thus strengthening overall macroeconomic stability, must be ensured. Euro area governments should prepare and communicate ambitious and realistic fiscal exit and consolidation strategies within the framework of the Stability and Growth Pact. 


\section{Conclusions}

Let me draw to a close.

I have described to you the profound changes in the environment in which we operate over the past two years. These changes have made it unavoidable that we take monetary policy measures that are unprecedented in nature, scope and magnitude. These measures fall into two categories: first, conventional measures in the form of interest rate changes; and second, a number of non-standard measures, which together constitute the ECB's policy toolkit of enhanced credit support. These are special and primarily bank-based actions we have taken to enhance the flow of credit above and beyond what could be achieved through interest rate reductions alone.

Let me once again emphasise that we conduct all our policies in full continuity of our mission which started ten years ago, with foundations that have a much longer history and which are well anchored in the most stable monetary policy in Europe the pursuit of price stability. Moreover, despite the need for the policy innovations I have described to address the particular economic challenges of our times, all our measures are deliberately designed in a way that they can be unwound once any upside risks to price stability should emerge.

I have also mentioned the existence of different approaches to crisis management of major central banks, which are related to differences in the structure of their economies and their institutional arrangements. Let me reiterate that we are all united in purpose. It is absolutely essential to ensure that inflation expectations remain firmly anchored in line with price stability over the medium term. This will contribute to what is lacking most, namely confidence on the part of households and companies, and will lay the groundwork for a return to sustainable prosperity.

Right now the scarcest resource we have is confidence in the future. That is why in the present, very demanding, circumstances all necessary steps should be taken to strengthen confidence at all levels. This calls for bold yet solidly anchored responses. We must maintain the appropriate balance between the need to take immediate action commensurate with the gravity of today's situation, and the equally undeniable obligation to return to a path that is sound and sustainable in the medium and long term. 
This is true for all policies: for monetary policy, for fiscal policies, and for executive branches' decisions to support the financial sector.

I would warn against a common and unfortunate view suggesting that it is currently too early, or even totally inopportune, to envisage appropriate exit strategies. Such a view is, in my opinion, plain wrong - for three reasons:

First, because decision-makers' primary quality is that they always display "sang froid" and keep their composure, particularly in the most demanding and turbulent times. Viewing today's actions and decisions from a longer-term perspective is part of the necessary intellectual discipline.

Second, because nobody should confuse the existence of a credible exit strategy which can be activated at the right moment - with the decision to actually embark on that strategy. Often such confusion explains people's fierce opposition to the mere existence of exit strategies.

And third, because the very existence and the visibility of a credible exit strategy will foster confidence today and will therefore contribute to the re-activation of the economy here and now. This is true for monetary policy: our 329 million fellow citizens are very profoundly attached to price stability in the medium term, and the credibility of our policy is essential for improving their confidence now.

This is equally true for fiscal policy: economic research has demonstrated that twothirds to three-quarters of European households are "Ricardian". This means that they consume less and save more if they lack confidence in the soundness of future public finances.

The anchoring of sound policies in a medium to long-term framework is more important than ever if we want to effectively counter the present adverse circumstances.

The ECB, for its part, will do all that is necessary to continue to be a solid and reliable anchor of stability and confidence in these challenging times.

Thank you for your attention. 


\section{CESifo Working Paper Series}

for full list see www.cesifo-group.org/wp

(address: Poschingerstr. 5, 81679 Munich, Germany, office@cesifo.de)

2773 Erdal Yalcin, Uncertain Productivity Growth and the Choice between FDI and Export, August 2009

2774 Klaus Abberger, Wolfgang Nierhaus and Shynar Shaikh, Findings of the Signal Approach for Financial Monitoring in Kazakhstan, September 2009

2775 Sascha O. Becker, Francesco Cinnirella and Ludger Woessmann, The Trade-off between Fertility and Education: Evidence from before the Demographic Transition, September 2009

2776 Thomas Aronsson and Erkki Koskela, Optimal Income Taxation, Outsourcing and Policy Cooperation in a Dynamic Economy, September 2009

2777 Joel Slemrod, Old George Orwell Got it Backward: Some Thoughts on Behavioral Tax Economics, September 2009

2778 Cagri Seda Kumru and Athanasios C. Thanopoulos, Social Security Reform and Temptation, September 2009

2779 Alessandro Bucciol and Roel M. W. J. Beetsma, Inter- and Intra-generational Consequences of Pension Buffer Policy under Demographic, Financial and Economic Shocks, September 2009

2780 Eduardo Strube and Marcelo Resende, Complementarity of Innovation Policies in the Brazilian Industry: An Econometric Study, September 2009

2781 Henry Tulkens and Vincent van Steenberghe, "Mitigation, Adaptation, Suffering": In Search of the Right Mix in the Face of Climate Change, September 2009

2782 Maria L. Loureiro, Anna Sanz-de-Galdeano and Daniela Vuri, Smoking Habits: Like Father, Like Son, Like Mother, Like Daughter, September 2009

2783 Momi Dahan, Tehila Kogut and Moshe Shalem, Do Economic Policymakers Practice what they Preach? The Case of Pension Decisions, September 2009

2784 Eytan Sheshinski, Uncertain Longevity and Investment in Education, September 2009

2785 Nannette Lindenberg and Frank Westermann, How Strong is the Case for Dollarization in Costa Rica? A Note on the Business Cycle Comovements with the United States, September 2009

2786 Leif Danziger, Noncompliance and the Effects of the Minimum Wage on Hours and Welfare in Competitive Labor Markets, September 2009 
2787 Gerlinde Fellner, Rupert Sausgruber and Christian Traxler, Testing Enforcement Strategies in the Field: Legal Threat, Moral Appeal and Social Information, September 2009

2788 Gabriel J. Felbermayr, Mario Larch and Wolfgang Lechthaler, Unemployment in an Interdependent World, September 2009

2789 Sebastian G. Kessing, Federalism and Accountability with Distorted Election Choices, September 2009

2790 Daniel Gros, Global Welfare Implications of Carbon Border Taxes, September 2009

2791 Louis N. Christofides, Michael Hoy and Ling Yang, The Gender Imbalance in Participation in Canadian Universities (1977-2005), September 2009

2792 Jan K. Brueckner and Robert W. Helsley, Sprawl and Blight, September 2009

2793 Vidar Christiansen and Stephen Smith, Externality-correcting Taxes and Regulation, September 2009

2794 John Beirne, Guglielmo Maria Caporale, Marianne Schulze-Ghattas and Nicola Spagnolo, Global and Regional Spillovers in Emerging Stock Markets: A Multivariate GARCH-in-mean Analysis, September 2009

2795 Rüdiger Pethig and Frieder Kolleß, Asymmetric Capital-Tax Competition, Unemployment and Losses from Capital Market Integration, September 2009

2796 Ngo Van Long, Horst Raff and Frank Stähler, Innovation and Trade with Heterogeneous Firms, September 2009

2797 Margit Osterloh and Bruno S. Frey, Research Governance in Academia: Are there Alternatives to Academic Rankings?, September 2009

2798 Thiess Buettner and Clemens Fuest, The Role of the Corporate Income Tax as an Automatic Stabilizer, September 2009

2799 Annette Alstadsæter, Measuring the Consumption Value of Higher Education, September 2009

2800 Peter Friedrich, Chang Woon Nam and Janno Reiljan, Local Fiscal Equalization in Estonia: Is a Reform Necessary?, September 2009

2801 Evžen Kočenda and Jan Hanousek, State Ownership and Control in the Czech Republic, September 2009

2802 Michael Stimmelmayr, Wage Inequality in Germany: Disentangling Demand and Supply Effects, September 2009

2803 Biswa N. Bhattacharyay, Towards a Macroprudential Surveillance and Remedial Policy Formulation System for Monitoring Financial Crisis, September 2009 
2804 Margarita Katsimi, Sarantis Kalyvitis and Thomas Moutos, "Unwarranted" Wage Changes and the Return on Capital, September 2009

2805 Christian Lessmann and Gunther Markwardt, Aid, Growth and Devolution, September 2009

2806 Bas Jacobs and Dirk Schindler, On the Desirability of Taxing Capital Income to Reduce Moral Hazard in Social Insurance, September 2009

2807 Hans Gersbach and Noemi Hummel, Climate Policy and Development, September 2009

2808 David E. Wildasin, Fiscal Competition for Imperfectly-Mobile Labor and Capital: A Comparative Dynamic Analysis, September 2009

2809 Johan Eyckmans and Cathrine Hagem, The European Union's Potential for Strategic Emissions Trading through Minimal Permit Sale Contracts, September 2009

2810 Ruediger Bachmann and Christian Bayer, The Cross-section of Firms over the Business Cycle: New Facts and a DSGE Exploration, October 2009

2811 Slobodan Djajić and Michael S. Michael, Temporary Migration Policies and Welfare of the Host and Source Countries: A Game-Theoretic Approach, October 2009

2812 Devis Geron, Social Security Incidence under Uncertainty Assessing Italian Reforms, October 2009

2813 Max-Stephan Schulze and Nikolaus Wolf, Economic Nationalism and Economic Integration: The Austro-Hungarian Empire in the Late Nineteenth Century, October 2009

2814 Emilia Simeonova, Out of Sight, Out of Mind? The Impact of Natural Disasters on Pregnancy Outcomes, October 2009

2815 Dan Kovenock and Brian Roberson, Non-Partisan 'Get-Out-the-Vote' Efforts and Policy Outcomes, October 2009

2816 Sascha O. Becker, Erik Hornung and Ludger Woessmann, Catch Me If You Can: Education and Catch-up in the Industrial Revolution, October 2009

2817 Horst Raff and Nicolas Schmitt, Imports, Pass-Through, and the Structure of Retail Markets, October 2009

2818 Paul De Grauwe and Daniel Gros, A New Two-Pillar Strategy for the ECB, October 2009

2819 Guglielmo Maria Caporale, Thouraya Hadj Amor and Christophe Rault, International Financial Integration and Real Exchange Rate Long-Run Dynamics in Emerging Countries: Some Panel Evidence, October 2009 
2820 Saša Žiković and Randall K. Filer, Hybrid Historical Simulation VaR and ES: Performance in Developed and Emerging Markets, October 2009

2821 Panu Poutvaara and Andreas Wagener, The Political Economy of Conscription, October 2009

2822 Steinar Holden and Åsa Rosén, Discrimination and Employment Protection, October 2009

2823 David G. Mayes, Banking Crisis Resolution Policy - Lessons from Recent Experience Which elements are needed for robust and efficient crisis resolution?, October 2009

2824 Christoph A. Schaltegger, Frank Somogyi and Jan-Egbert Sturm, Tax Competition and Income Sorting: Evidence from the Zurich Metropolitan Area, October 2009

2825 Natasa Bilkic, Thomas Gries and Margarethe Pilichowski, Stay in School or Start Working? - The Human Capital Investment Decision under Uncertainty and Irreversibility, October 2009

2826 Hartmut Egger and Udo Kreickemeier, Worker-Specific Effects of Globalisation, October 2009

2827 Alexander Fink and Thomas Stratmann, Institutionalized Bailouts and Fiscal Policy: The Consequences of Soft Budget Constraints, October 2009

2828 Wolfgang Ochel and Anja Rohwer, Reduction of Employment Protection in Europe: A Comparative Fuzzy-Set Analysis, October 2009

2829 Rainald Borck and Martin Wimbersky, Political Economics of Higher Education Finance, October 2009

2830 Torfinn Harding and Frederick van der Ploeg, Is Norway's Bird-in-Hand Stabilization Fund Prudent Enough? Fiscal Reactions to Hydrocarbon Windfalls and Graying Populations, October 2009

2831 Klaus Wälde, Production Technologies in Stochastic Continuous Time Models, October 2009

2832 Biswa Bhattacharyay, Dennis Dlugosch, Benedikt Kolb, Kajal Lahiri, Irshat Mukhametov and Gernot Nerb, Early Warning System for Economic and Financial Risks in Kazakhstan, October 2009

2833 Jean-Claude Trichet, The ECB's Enhanced Credit Support, October 2009 